\title{
Bequest and Wealth Accumulation: Are Some Pieces of the Puzzle Missing?
}

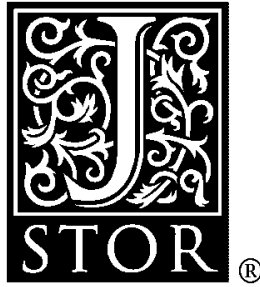

\author{
Denis Kessler; André Masson
}

The Journal of Economic Perspectives, Vol. 3, No. 3. (Summer, 1989), pp. 141-152.

Stable URL:

http://links.jstor.org/sici?sici=0895-3309\%28198922\%293\%3A3\%3C141\%3ABAWAAS\%3E2.0.CO\%3B2-F

The Journal of Economic Perspectives is currently published by American Economic Association.

Your use of the JSTOR archive indicates your acceptance of JSTOR's Terms and Conditions of Use, available at

http://www.jstor.org/about/terms.html. JSTOR's Terms and Conditions of Use provides, in part, that unless you have obtained prior permission, you may not download an entire issue of a journal or multiple copies of articles, and you may use content in the JSTOR archive only for your personal, non-commercial use.

Please contact the publisher regarding any further use of this work. Publisher contact information may be obtained at http://www.jstor.org/journals/aea.html.

Each copy of any part of a JSTOR transmission must contain the same copyright notice that appears on the screen or printed page of such transmission.

The JSTOR Archive is a trusted digital repository providing for long-term preservation and access to leading academic journals and scholarly literature from around the world. The Archive is supported by libraries, scholarly societies, publishers, and foundations. It is an initiative of JSTOR, a not-for-profit organization with a mission to help the scholarly community take advantage of advances in technology. For more information regarding JSTOR, please contact support@jstor.org. 


\title{
Bequest and Wealth Accumulation: Are Some Pieces of the Puzzle Missing?
}

\author{
Denis Kessler and André Masson
}

$\Omega$ he lively debate between Laurence J. Kotlikoff and Franco Modigliani presented in the Spring 1988 issue of this journal concerns an old question: what is the main motivation for saving and therefore for the accumulation of wealth? More specifically, what are the respective contributions to aggregate wealth of (1) saving for retirement (also known as "hump" saving); (2) precautionary savings (and "unintended" bequests) due to uncertainty about the length of life; and (3) planned bequests? Of course, other wealth holding motives are possible, but let us follow Kotlikoff and Modigliani in setting them aside for now. If Modigliani's life cycle hypothesis is to be viewed as a close to approximation of reality, then the bulk of existing wealth should have resulted from some combination of hump and precautionary saving.

Our comment on this dispute attempts to advance two issues. First, the controversy involves an enormous gap between empirical estimates of the share of "inherited wealth" in total accumulation, even though the estimates are often based on the same data. We hope to clarify why the estimates vary so widely. Second, the Kotlikoff/Modigliani dispute is presented as an American issue, with little extension abroad. We will present some results from other countries that bear on the controversy. (Some of the estimates from Kotlikoff's paper originated in a 1981 paper he wrote with Lawrence Summers, which is why we sometimes refer to his position as the "Kotlikoff-Summers" argument in this comment.)

The problem of conceptualizing the contribution of bequest to aggregate savings can be summarized with a thought experiment. Assume all bequests were confiscated.

- Denis Kessler is Professor of Economics at the University of Nancy. André Masson is a Senior Research Fellow at the Centre National de la Recherche Scientifique (C.N.R.S.). Both belong to the Centre d'Etudes et de Recherches sur l'Epargne, le Patrimoine et les Inégalités (C.E.R.E.P.I.), Paris, France. 
By how much (in steady state) would wealth be diminished? The resulting reduction in savings might be thought as one measure of the wealth due to inheritance (or intergenerational gifts).

The theoretical debate appears more clearly in this setting. Kotlikoff and Modigliani adopt different definitions of what should be counted as an intergenerational transfer. Further, for a given level of transfers, they diverge in their computation of how much inherited wealth would result.

If one does not inquire too closely as to how confiscating all bequests would affect government expenditures or consumers' behavior, the reduction in wealth that would result from confiscating all intergenerational transfers would be equal to the sum of transfers received and the savings out of transfer income, along with accumulated interest. ${ }^{1}$ In effect, Kotlikoff's position presumes that all of transfer income is added to the savings of the recipient, while Modigliani presumes that none of transfer income is added to savings. In the likely event that the savings rate out of intergenerational transfers lies between these extremes, ${ }^{2}$ Kotlikoff's measure of the contribution of bequest will be upward biased, and Modigliani's downward biased.

\section{What is Meant by the "Contribution of Bequest to Savings"?}

Any measurement of the contribution of transfers to wealth accumulation rests on a specific theory of saving behavior. The fundamental source of the KotlikoffModigliani dispute seems to rest in the fact that these authors do not share the same representation of accumulation behavior, the same view of the forces driving bequest, or the same conception of the family. In this perspective we list eight issues that appear especially relevant to choosing a perspective on savings behavior. ${ }^{3}$

\section{Who makes consumption-saving decisions?}

Is it the (independent) individual, the household or the dynastic family? The life cycle hypothesis claims that the relevant saving unit is the household, abstracting from

\footnotetext{
${ }^{1}$ More precisely, an inheritance $I$ received at age 0 corresponds at age $t$ to an inherited wealth $H(t)$ equal to $I \exp \left(r \int_{0}^{t} s(a) d a\right)$, with $s(a)$ the rate of saving out of bequest income at age $a$. $s(a)$ equals zero for Modigliani, one for Kotlikoff.

${ }^{2}$ If consumers adopt a pure forward looking behavior, the (lifetime) propensity to save out of capital receipts should be the same as the one out of human resources; the high inheritance elasticity of wealth (0.6) obtained, everything being equal, on French data seems to show, however, that saving out of capital receipts is markedly larger (Masson, 1988).

${ }^{3}$ For a thorough analysis of the gap between Kotlikoff and Summers's and Modigliani's measures and a tentative reconciliation, see Blinder (1988). He sides with Modigliani in defining transfers narrowly, but stresses the need for a behavioral economic model to determine the level of savings in the absence of inheritances. Moreover, he concentrates on the surprising discrepancies between results obtained with different methods of estimation and declares the crucial issue concerning the value of durable services "nonjudiciable," as long as additional data are not available.
} 
the intra- or inter-generational relations among its members, and giving limited consideration to the links between parents and children in different households. The individual approach will, to the contrary, take into account some intra-household transfers that may affect individual accumulation. In a dynastic approach (Barro, 1974), the relevant saving decision unit is the dynastic family whose foundation lies precisely in transfers.

2. Is it reasonable to assume separability between material bequests and expenditures made on behalf of children? What about assuming separability between saving choices and labor supply or human capital decisions?

The life cycle hypothesis assumes this separability: in this model, the bequest motive is considered in isolation and the process of asset accumulation can be considered relatively apart from labor supply or family-related decisions. Other models assume a large substitutability between material transfers from parents to children and expenditures by parents on behalf of children: Becker for instance claims that, in proportion to total resources, poor people may save intergenerationally as much as rich people, but mainly in a "human" form (child-rearing costs, expenditures on education... in the form of time or money).

This question is illustrated in the decision by Kotlikoff and Summers to count the cost of a college education as an intergenerational transfer, because such payments appear to be a main component of the expenditures parents make on their "adult" children (above the age of 18). To evaluate their position, one has first to look at parents' motivations: college tuition may be assimilated to transfers if parents substitute such educational expenses with material gifts bestowed to other children, or if some parents prefer to invest in the college education of their children while others choose to make bequests. But a complete assimilation supposes also, on the recipient side, that college education has the same impact on later accumulation as a cash transfer. In practice, it is not sure that both conditions are satisfied; moreover, in keeping with this perspective, almost any expenditure on behalf of children or family could be counted as an intergenerational transfer, leading to an inflated measurement of the ratio of inherited wealth (in human and nonhuman form) to existing nonhuman wealth.

Most students of saving will therefore side here with Modigliani's definition of transfers: inheritances and major gifts. However, it's worth remembering the somewhat artificial line drawn between "major" gifts, which are presumed to add to wealth, and "minor" gifts, which are taken to increase consumption.

3. How can economists identify the inherited and life cycle components of wealth, since the two types of accumulation interact?

Receiving inherited wealth does change life cycle savings, with the effect depending on the size and timing of the bequest. An inheritance received at a young age is likely to boost accumulation, especially given strong market imperfections and uncertainties. How can such interactions be quantified and be divided between the two factors to reach a true measure of the impact of bequests? 


\section{Can economists infer the contribution of bequest to saving from a retrospective} (historical) accounting method, that tries to trace back and to cumulate inheritance received in the past by existing cohorts?

It seems questionable to evaluate the contribution of bequests to wealth by the share of already inherited wealth, since this method depends upon past economic growth and ignores the incidence of expected inheritances on saving. As an alternative, it would be useful to divide existing wealth into a part earmarked for bequest and a part devoted to life cycle consumption. The problem with this approach is that these two components of wealth are not observable. (This is the root of the controversy between Darby and Modigliani, described in the "Alternative Approach" section of Modigliani's paper in the journal.)

In fact, using the "flow of bequest" method tends to obscure these interactions between transfers and consumption by forcing the analyst to rely on steady state and average behavior assumptions: the representative household of a cohort who has received a certain inheritance at a certain age must leave a bequest that preserves the steady state with a given rate of economic growth, and so on. ${ }^{4}$

\section{Should people be considered primarily life cyclers or inheritors and bequeathers?}

Given the skewed distribution of wealth and the even more skewed distribution of inheritances, it is insufficient to consider only the importance of transfers in aggregate accumulation. The statement that bequests lead to half of total wealth could correspond to two very different situations: in one, the (age-adjusted) share of inheritance in total wealth is 50 percent for everybody; in the second, the top quintile of wealth holders owns three-quarters of total assets (as in the United States) and has inherited two-thirds of its wealth, whereas the bottom 80 percent of the wealth distribution receives and bequeaths nothing. The role of inheritance on wealth inequality and the relevance of the life cycle hypothesis are not at all the same in the two situations.

\section{Why do people bequeath?}

The debate offers a distinction between true, planned bequests and accidental unplanned bequests. Unintended bequests may be due to uncertain length of life in a world of imperfect annuity markets or to imperfect rental markets for housing and other durable assets (Bevan and Stiglitz, 1979). Either way, they blur the black-white distinction between life cycle and bequest accumulation. Davies (1981) has shown that the precautionary motive alone (unintended bequests providing no direct utility) can lead to sizeable transfers that are not caused by a genuine bequest motive. However, Modigliani (and Bevan and Stiglitz) point out that households do derive some utility even from an unintended bequest, so that the two motives interact. For example, dwellings are held at old age both for the services they yield or as insurance of consumption against longevity, and as a source of bequests to the children if not used up. Although it might be said that life cycle motives are more important for more

\footnotetext{
${ }^{4}$ See Diamond (1985), who points out that there is hence no effect of inheritance-bequests on consumption if the rate of interest equals the rate of growth; in this case, a sizeable impact of transfers could be obtained by simply allowing for some diversity in behaviors or situations in the population.
} 
households in this context, the absence of separability makes it virtually impossible to distinguish life cycle from bequest savings.

The motivation of inheritance (as discussed by Kotlikoff) is also important to understand for policy purposes. For instance, if bequests are of a "compensatory" type, driven by strong altruism, the consumer will react to higher estate taxation by "increasing his bequest so as to cushion the impact on his heirs" (Blinder, 1976). The inheritance elasticity of wealth may then be very small or even negative. In a similar case, Stiglitz (1978) emphasizes how taxation may lead to greater wealth inequality.

\section{Are life cycle savings and bequests the only two motives for accumulation?}

This dichotomy may seem reasonable, since all excess life cycle accumulation winds up as bequeathed wealth. But economists may be understating other motives for holding wealth, such as power, entrepreneurship, social prestige, and so on, motives which may not be confined to the super-rich. Those determinants of saving are more or less ignored in most saving models, but they may play an important role in the debate concerning the status of accumulated interest on inheritance. Consider how the effect of bequests on total wealth will differ in two models of social savings behavior.

Consider first the case of the capitalists (or rentiers) of a Kaldor-Pasinetti type, whose income is derived almost entirely from property, initially inherited. Their lifecycle accumulation is assumed to be negligible in relative terms, and nearly all their wealth is destined to be bequeathed. But these rentiers will also save simply because they derive utility directly from owning assets. Indeed, to keep their social position and their economic power, they have to maintain their relative wealth share, which means that their wealth must increase as quickly as general economic growth. If the available rate of return equals the rate of growth, then all the income from inheritance must be saved to preserve the relative size of the bequest, and the Kotlikoff-Summers measure of the impact of bequests will be correct. ${ }^{5}$ Modigliani's measure, on the other hand, is clearly inappropriate in this context, since it will treat as life cycle saving an accumulation which is never intended to be spent.

Consider next a traditional stationary society where, as in Atkinson (1971), someone inheriting a given bien de famille may use the income from it, but has to hold the asset intact until he dies, when it passes to the next generation. There are no other transfers. Since the rate of saving out of bequest income is nil, this society is closer to Modigliani's measure of inherited wealth. Since Kotlikoff and Summers treat the income from the bequest as part of the bequest, their evaluation of the impact of bequests on saving will be overestimated if the rate of interest is positive.

\section{Does the value of the contribution of bequests to total saving allow for a decisive test of the life cycle hypothesis?}

Kotlikoff admits that his preferred measure of the share of inherited wealth may represent wealth holding motives other than the transmission of an estate. The Kotlikoff-Summers model was designed to test a specific null hypothesis: Can a

\footnotetext{
${ }^{5}$ In this golden rule case, the contribution of bequest of saving will be almost 100 percent. Note however that it will be superior to one if the rate of return exceeds the rate of growth.
} 


\section{Figure 1}

\section{The Age-Wealth Profile of the Life Cycle Saver}

\section{With and Without Inherited Wealth}

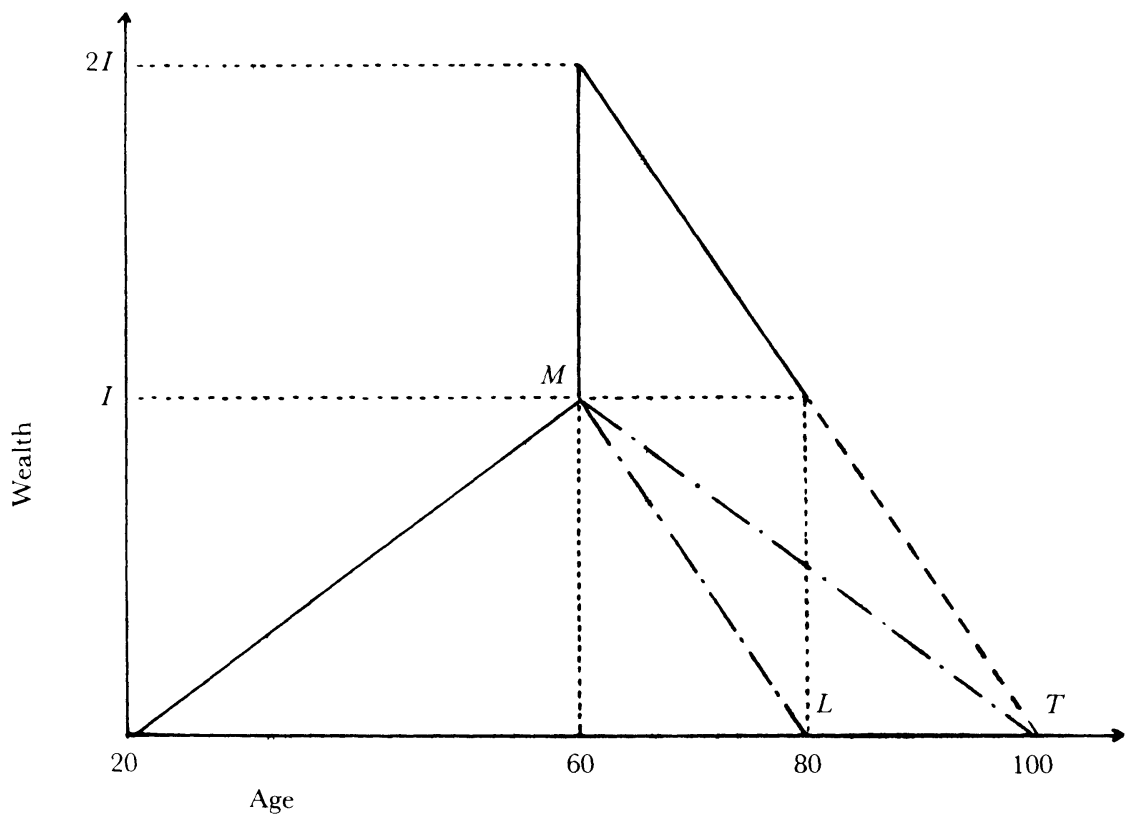

zero-bequest life-cycle model explain the bulk of aggregate saving? Or to put the question another way: What would have been the level of saving today (whether life cycle saving or not) in the absence of any earlier intergenerational transfers? To answer the question, they cumulate for each existing cohort the difference between past streams of labor earnings and consumption. Of course, one shortcoming of this method is that if bequests had indeed been outlawed, earnings and consumption would have been quite different. But the procedure can also be criticized on other grounds.

To understand the major flaw of the Kotlikoff-Summers procedure when regarded as a test of the life cycle hypothesis, examine a hypothetical (stationary) society, composed only of strict life cyclers with high risk aversion (and thus important precautionary bequest), whose accumulation pattern is depicted in Figure 1. People leave their parents and have children at age 20, retire at age 60 with no pension wealth, and can live to a maximum age of 100 , expected age at death being 80 . They accumulated wealth from scratch up to a peak at age 60 , equal to $I$, where they receive the same amount $I$ in inheritance. Being extremely risk averse, they plan then to decumulate linearly as if they were sure to live to be $100 .^{6}$ The average person actually dies at 80, leaving an unintended bequest of $I$.

\footnotetext{
${ }^{6}$ This cautious behavior can be derived from Leontief preferences (maximization of the minimum value of discounted instantaneous utility), with appropriate time discounting: a linear decumulation of wealth after retirement can be obtained with increasing impatience and a rate of time depreciation proportional to the prevailing rate of interest (the age earnings profile is then chosen as to generate a linear accumulation before age 60 ).
} 
How much do bequests contribute to total wealth, if (to simplify) everyone exhibits this average behavior? For any age after retirement, one would like to say that this share is 50 percent, implicitly assuming that self-accumulated wealth and inheritance are consumed at the same rate (self-accumulated wealth following profile $M T$ in Figure 1). For the entire population, inherited wealth would be $15 I$ for a total accumulation of $50 \mathrm{I}$, making the contribution of bequests to savings equal to 30 percent. Since the rate of saving out of transfer income is negative (because of when it is received in life), both the Modigliani and Kotlikoff measures will overestimate its true share. Modigliani assumes that inheritance is kept intact and that life cycle wealth is entirely consumed at age 80 (following profile $M L$ in Figure 1), which leads to an estimate that bequests are 40 percent of total wealth. Using a 5 percent rate of interest, Kotlikoff's assumption that all of bequests are saved will lead to an estimate that 66.1 percent of total wealth consists of bequests. In short, he would argue that two-thirds of wealth may be due to inheritance even in a pure life cycle society!

Another way of describing the difference between the two viewpoints is that the Kotlikoff-Summers procedure leads to reconstituting only one component of wealth, self-accumulated savings, while the "flow of bequests" method deals solely with inherited wealth. More flexible measures could be derived from frameworks which could draw upon both life cycle accumulation and capital transfers and could then be checked against available wealth data (see Davies and Shorrocks, 1976).

Without such complete models, disputes about data are bound to happen, as the exchange in the journal amply illustrates. Kotlikoff, for example, writes that "actual age earnings and age consumption profiles... have essentially identical shapes and levels prior to age 45." Modigliani writes that "households have, on average, substantial saving and net worth at least after age $25 \ldots$. This rise of wealth (between age 25 and age 45) cannot be attributed to inheritance to any significant extent, since ... the receipt of important inheritance is rare before 45." We do not claim to know who is right, but there is obviously a problem here that comprehensive models of wealth accumulation and distribution might help to solve.

Finally, this dispute about data, as well as the other elements of the debate, reveal a more fundamental opposition between Kotlikoff and Modigliani concerning the approach to accumulation behavior. The authors seem reluctant to admit that there is no single correct decomposition of wealth into inherited and self-accumulated parts. The range of alternatives depends upon how one views the role of inheritance and how one interprets the share of inherited wealth.

\section{French and Canadian Estimates of the Bequest Share of Total Wealth}

Empirical estimates of the bequest share of total wealth in other countries pose many of the same problems of interpretation that beset the Kotlikoff-Modigliani exchange. However, they still provide a useful check on the general magnitudes being used as the basis of discussion. College education costs have not been estimated. 
The "flow of bequests" method has been applied to France by Babeau (1988) for the year 1984. Net worth in the middle of the year amounted to 11,800 billion French francs (FF). Estimates of total net intergenerational transfers (excluding those between spouses) are based primarily on the taxable amount of gifts and inheritances. When a small adjustment is made for undeclared transfers, Babeau estimates a total amount of net transfers of 112 billion FF. For a 4 percent rate of steady growth and an average intergenerational age difference of 25 years, using Modigliani's rule, inherited wealth would be 16 percent of total wealth; if the growth rate is 2 percent and the age difference is 30 years, the share rises to 23 percent. The range of variation is therefore slightly higher than the 12 to 20 percent range found by Modigliani for the United States and the United Kingdom. If the Kotlikoff and Summers measures are used, with a rate of interest of 3 percent, the bequest share of total wealth is 22 percent in the first case and 35 percent in the second. ${ }^{7}$

A second measure of the share of inherited wealth in total wealth is based on a French survey of 2000 households conducted in 1975 by the Centre de Recherche Economique sur l'Epargne (Kessler and Masson, 1979). People were asked if they had received any inheritance above 20,000 FF (1975 French francs), or any gifts above $10,000 \mathrm{FF}$, and if so, to give an estimation of its value in 1975 French francs. Other questions attempted to make a computation of net worth by asking about different assets held, although durables were not included. The questionnaire also required detailed information about the present allocation of inherited wealth, inheritance expectations and wealth already bestowed to children.

It is well known that such data suffer from recall bias and underreporting, especially in people's tendency to admit more easily that they have given than that they have received. The bias seems quite significant in some U.S. surveys, such as the Economic Behavior of the Affluent (1964), where donors appear far more numerous than gifts recipients (Kessler, 1987). This bias exists in the French data, too, but it is of surprisingly limited importance. At any rate, these data allow a direct comparison with U.S. survey estimates of the share of bequest, based upon Modigliani's definition.

Of the households in the survey, 36 percent have already received some bequest. Inherited wealth is 35 percent of total wealth for the entire population (the mean value of capital receipts is $194,000 \mathrm{FF}$ per beneficiary and average net worth is $200,000 \mathrm{FF}){ }^{8}$ Among beneficiaries only, who are on average 2.4 times richer than the

\footnotetext{
${ }^{7}$ Taking advantage of the fact that these estate data also give the age distribution of gifts and inheritance, Laferrière (1988) has computed the ratio of inherited wealth to total wealth at different ages. The average of this ratio provides another measure of the contribution of bequest to saving, based upon the steady state hypothesis of an invariant age distribution of transfers (as in note 9). With a 3 percent rate of interest $(r$ ) and a 4 percent rate of growth $(n)$, the share of discounted inherited wealth is around 5 percent before the age of 40 ; it rises to one fifth between 40 and 60 , and exceeds one third after that age. Its average value of 24 percent is in this case comparable to the "flow of bequest" method estimate; it is, however, much more sensitive to the differential $r-n$, and depends crucially on the importance of transfers received early in life (see Kotlikoff's paper, p. 45-46).

${ }^{8}$ If cumulated interest on inheritance is added, at an annual interest rate between 2 and 3 percent, inherited wealth rises to about 46 percent of total wealth for the entire population.
} 
representative household, inherited wealth is around 40 percent of total wealth. In short, French estimates of Modigliani's measure appear roughly twice as high as the U.S. ones. This might again mean that inheritance plays a more important role in France, an old country being compared with a new country.

Simulation models present another way of measuring the importance of bequests. We will briefly describe an accounting model that uses French data, and the behavioral model of Davies (1982), which applies to Canada.

The general idea of the accounting simulation model, which uses French data, is to use all existing statistics concerning income, saving, capital gains, loans, and so on to compute annual wealth variations for each age and each occupational group from 1949 to 1975 . Reconstituted cross-sectional wealth distributions are checked against actual wealth data, which is available for several years of the period. Inheritance transfers are however calculated within the model, and then estate statistics are used as a reality check. Moreover, to eliminate short-term variations and capture the structural features of the postwar period, a steady state wealth distribution has been generated for the model simulations using average, representative data kept constant in time. This simulation accounting model is called EPHEBE. Masson (1986) provides a complete description.

The importance of inherited wealth can be derived from the steady state distribution, while taking into account the per capita growth rate of growth of wealth which is between 3 and 4 percent over the postwar period. ${ }^{9}$ The importance of inherited wealth decreases with a rise in the growth rate. Following Modigliani's definition, the share of inherited wealth in total wealth is about 40 percent. These figures should be considered with caution, owing to the complexity of the method of estimation, but they appear to agree with corresponding estimates derived from survey data. With a rate of interest between 2 and 3 percent over the period, the analogous Kotlikoff and Summers measure would put inherited wealth at 50 to 55 percent of total wealth.

Davies' work (1982) is one of the best-known bequest augmented-life cycle model of wealth distribution. The benchmark is the distribution of wealth in Canada in 1970. The microsimulation concerns the accumulation behavior of one cohort through its life cycle, starting from an exogenous distribution of inheritance derived from actual wealth data, parents' mortalities probabilities and other factors, including estate splitting rules between spouses and children. The model is tailored as to generate the appropriate distribution of bequests for steady-state growth; that is, the model seeks to replicate the initial distribution of inheritance for children and to find the same

\footnotetext{
${ }^{9}$ In this steady state, age cross-sections and cohort profiles of real wealth coincide for each occupational group, except for the growth of wealth per capita at a rate $n^{\prime}$. Demographic weights are given exogenously, as in 1975. If $I(a)$ is average capital transfers received at age $a$, the average inherited wealth for households aged $t$ is: $H(t)=\sum_{a} I(t-a) /\left(1+n^{\prime}\right)^{a}$. If these households represent a fraction $f(t)$ of total population, the share of inherited wealth, $h$, satisfies ( $\bar{W}$ being mean wealth): $h=\Sigma_{t} f(t) H(t) / \bar{W}$, according to Modigliani's definition. Taking into account accumulated interest on inheritance at an annual rate $r$ comes to the same as replacing $n^{\prime}$ by $n^{\prime}-r$ in the computation of $H(t)$.
} 
correlation between human capital and inheritance for parents and children. Bequests are of the "compensatory" Beckerian type, negatively correlated to children's income. ${ }^{10}$ The life cycle part of the model focuses on age variations in family size but assumes certainty about length of life and does not consider risk aversion.

From this model, Davies and St-Hilaire (1987) obtain the following results (p. 107-8). The share of inherited wealth is found to be 35 percent under Modigliani's definition; the corresponding Kotlikoff and Summers measure, including cumulated interest on inheritance, is 53 percent; these figures fall in the same range as the French estimates but appear higher than the U.S. ones. ${ }^{11}$ Moreover, the simulation model of Davies (1982, Table 1, p. 489) allows a computation of the reduction of wealth that would be induced by the elimination of bequests, while taking into account behavioral responses: if inheritances were taxed at 100 percent, mean wealth drops from $\$ 29,017$ to $\$ 16,793$, suggesting that 42 percent of savings is due to inheritance, an intermediate value between the Modigliani and Kotlikoff-Summers measures. ${ }^{12}$

\section{Conclusions}

The controversy about the importance of intergenerational transfers to total saving is stimulating and opens more doors than it closes. The different approaches proposed, and especially the share of already inherited wealth in total wealth, suffer from a problem of circularity: the measure depends closely upon each author's prior belief concerning the true model of accumulation. Moreover, methods of estimation of the share of bequest are likely to lead to biased estimates because they focus on average behavior in a steady state framework and reconstitute only the inherited or the noninherited component of net worth, without trying to draw a comprehensive framework for the accumulation and distribution of total net worth.

U.S. survey data of the 1960s, which generally found that bequests accounted for only 15 to 20 percent of total wealth, gave a mistaken impression that bequests play a minor role in wealth accumulation and could be crudely specified, or even ignored, in the study of average saving behavior. It is to the credit of Kotlikoff and Summers to

\footnotetext{
${ }^{10}$ Parents' utility depends on children's anticipated welfare (although parents do not take into account the fact that children may also bequeath to their progeny). Bequests depend then crucially on the degree of intergenerational correlation for income (Davies chooses a correlation of .707 between the logarithms of father's and son's human capitals). Negative bequests or net worth are forbidden. Estate splitting rules between surviving spouse and children are furthermore introduced. The model obtains realistic distributions for current income and net worth as well as for bequest. Although the results appear robust under mild changes of the parameters, it has not been checked if alternative specifications of bequest or life cycle savings (giving less or more importance to inheritance in aggregate accumulation) could as well reproduce the observed distributions.

11. The present value of lifetime inheritance is 6 percent of total life resources (including human capital). Using the Morgan et al. (1962) survey, Blinder (1976) finds a ratio of lifetime inheritance to lifetime resources around 2.5 percent. In the French survey, the corresponding ratio is at least 5 percent. Bequests appear thus relatively less important in the United States than in France or Canada, but the rate of aggregate saving is also lower in the United States.

${ }^{12}$ We are grateful to Jim Davies for drawing our attention to this result.
} 
have pointed out that these figures do not necessarily give the last word about the importance of intergenerational transfers. Indeed, it is hard to reject Kotlikoff's view that bequests play a "sizeable" role in saving, even if one believes in the end that bequests are not the predominant factor of accumulation. On the other hand, the claim from the first Kotlikoff and Summers paper that bequests represent 80 percent of existing U.S. wealth appears exaggerated, at least without further qualification: surely, the United States is not composed mainly of rentiers.

- The authors wish to thank Franco Modigliani and Larry Kotlikoff for their help in clearing some elements of the debate, and Jim Davies, Joseph Stiglitz and Timothy Taylor for very valuable suggestions. 


\section{References}

Atkinson, Anthony, "The Distribution of Wealth and the Individual Life Cycle," Oxford Economic Papers, 1971, 23, 239-254.

Babeau, André, Le patrimoine aujourd'hui, Nathan, Paris, 1988.

Barlow, Robin, Harvey E. Brazer, and James Morgan, Economic Behavior of the Affuent. Data file distributed by ICPSR, University of Michigan, 1964.

Barro, Robert, "Are Government Bonds Net Wealth?" Journal of Political Economy, December 1974, 82, 1095-1117.

Bevan, David L., and Joseph E. Stiglitz, "Intergenerational Transfers and Inequality," Greek Economic Review, August 1979, 1, 8-26.

Blinder, Alan, "Inequality and Mobility in the Distribution of Wealth," Kyklos, 1976, 2, 607-638.

Blinder, Alan, Comments on Franco" Modigliani's "Measuring the Contribution of Intergenerational Transfers to Total Wealth." In Kessler, Denis and André Masson, eds., Modelling the Accumulation and Distribution of Wealth. Oxford: Oxford University Press, 1988, 68-76.

Davies, James, "Uncertain Lifetime, Consumption, and Dissaving in Retirement," Journal of Political Economy, June 1981, 89, 561-577.

Davies, James, "The Relative Impact of Inheritance and Other Factors on Economic Inequality," The Quarterly Joumal of Economics, August 1982, 97, 81-114.

Davies, James, and Anthony Shorrocks, "Assessing the Quantitative Importance of Inheritance in the Distribution of Wealth," Oxford Economic Papers, March 1978, 30, 138-149.

Davies, James, and France St-Hilaire, "Reforming Capital Income Taxation in Canada," Minister of Supply and Services of Canada, Ottawa, 1987.

Diamond, Peter, "Comment on Mervyn King 'The Economics of Saving: a Survey of Recent Contributions'," in Arrow, K., and S. Hankapohja, eds., Frontiers of Economics. Oxford: Basil Blackwell, 1985, 298-302

Kessler, Denis, "Comments on Michael Hurd." In Lipsey, R., and H. Tice, eds., The Measurement of Saving, Investment and Wealth. Chicago: Univer- sity of Chicago Press, forthcoming.

Kessler, Denis, and André Masson, "Les transferts intergénérationnels: l'aide, la donation, l'héritage," C.N.R.S. Report, Paris, 1979.

Kotlikoff, Laurence and Lawrence Summers, "The Contribution of Intergenerational Transfers to Total Wealth: a Reply." In Kessler, Denis, and André Masson, eds., Modelling the Accumulation and Distribution of Wealth. Oxford: Oxford University Press, 1988.

Kotlikoff, Laurence, and Lawrence Summers, "The Role of Intergenerational Transfers in Aggregate Capital Accumulation," Joumal of Political Economy, August 1981, 89, 706-32.

Kotlikoff, Laurence J., "Intergenerational Transfers and Savings," Journal of Economic Perspectives, Spring 1988, 2, 41-58.

Laferrère, Anne "La part héritée de la fortune: entre le quart et la moitié," Les ménages. Mélange en l'honneur de Jacques Desabie, INSEE October 1988.

Masson, André, "A Cohort Analysis of AgeWealth Profiles Generated by a Simulation Model in France (1949-1975)," Economic Joumal, March 1986, 96, 173-190.

Masson, André, "Permanent Income, Age and the Distribution of Wealth," Annales d' Economie et de Statistique, March 1988, 9, 227-256.

Modigliani, Franco, "Life Cycle, Individual Thrift and the Wealth of Nations," American Economic Review, June 1986, 76, 297-313.

Modigliani, Franco, "The Role of Intergenerational Transfers and Life Cycle Saving in the Accumulation of Wealth," Journal of Economic Perspectives, Spring 1988, 2, 15-40.

Morgan, James N., et al., Incume and Welfare in the United States. New York: McGraw-Hill, 1962.

Mundaca, Gabrielle, "The Importance of Gifts and Inheritances among the Very Wealthy." In Lipsey, R., and H. Tice, eds., The Measurement of Savings, Investment and Wealth. Chicago: University of Chicago Press, forthcoming.

Stiglitz, Joseph E., "Equality, Taxation and Inheritance," in Personal Income Distribution, Krelle, W. and A. F. Shorrocks, eds., Amsterdam: North-Holland, 1978, 271-298. 
http://www.jstor.org

\title{
LINKED CITATIONS
}

- Page 1 of 2 -

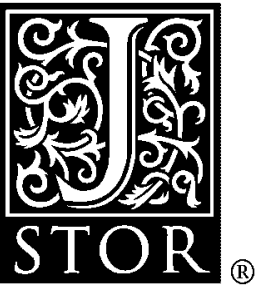

You have printed the following article:

Bequest and Wealth Accumulation: Are Some Pieces of the Puzzle Missing?

Denis Kessler; André Masson

The Journal of Economic Perspectives, Vol. 3, No. 3. (Summer, 1989), pp. 141-152.

Stable URL:

http://links.jstor.org/sici?sici=0895-3309\%28198922\%293\%3A3\%3C141\%3ABAWAAS\%3E2.0.CO\%3B2-F

This article references the following linked citations. If you are trying to access articles from an off-campus location, you may be required to first logon via your library web site to access JSTOR. Please visit your library's website or contact a librarian to learn about options for remote access to JSTOR.

\section{References}

The Distribution of Wealth and the Individual Life-Cycle

A. B. Atkinson

Oxford Economic Papers, New Series, Vol. 23, No. 2. (Jul., 1971), pp. 239-254.

Stable URL:

http://links.jstor.org/sici?sici=0030-7653\%28197107\%292\%3A23\%3A2\%3C239\%3ATDOWAT\%3E2.0.CO\%3B2-8

\author{
Are Government Bonds Net Wealth? \\ Robert J. Barro \\ The Journal of Political Economy, Vol. 82, No. 6. (Nov. - Dec., 1974), pp. 1095-1117. \\ Stable URL: \\ http://links.jstor.org/sici?sici=0022-3808\%28197411\%2F12\%2982\%3A6\%3C1095\%3AAGBNW\%3E2.0.CO\%3B2-1
}

\section{Uncertain Lifetime, Consumption, and Dissaving in Retirement}

James B. Davies

The Journal of Political Economy, Vol. 89, No. 3. (Jun., 1981), pp. 561-577.

Stable URL:

http://links.jstor.org/sici?sici=0022-3808\%28198106\%2989\%3A3\%3C561\%3AULCADI\%3E2.0.CO\%3B2-A

\author{
The Relative Impact of Inheritance and other Factors on Economic Inequality \\ James B. Davies \\ The Quarterly Journal of Economics, Vol. 97, No. 3. (Aug., 1982), pp. 471-498. \\ Stable URL: \\ http://links.jstor.org/sici?sici=0033-5533\%28198208\%2997\%3A3\%3C471\%3ATRIOIA\%3E2.0.CO\%3B2-F
}


http://www.jstor.org

\section{LINKED CITATIONS \\ - Page 2 of 2 -}

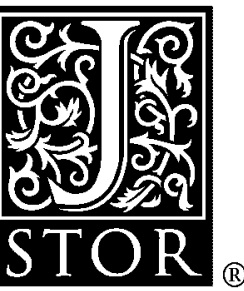

Assessing the Quantitative Importance of Inheritance in the Distribution of Wealth

J. B. Davies; A. F. Shorrocks

Oxford Economic Papers, New Series, Vol. 30, No. 1. (Mar., 1978), pp. 138-149.

Stable URL:

http://links.jstor.org/sici?sici=0030-7653\%28197803\%292\%3A30\%3A1\%3C138\%3AATQIOI\%3E2.0.CO\%3B2-W

The Role of Intergenerational Transfers in Aggregate Capital Accumulation

Laurence J. Kotlikoff; Lawrence H. Summers

The Journal of Political Economy, Vol. 89, No. 4. (Aug., 1981), pp. 706-732.

Stable URL:

http://links.jstor.org/sici?sici=0022-3808\%28198108\%2989\%3A4\%3C706\%3ATROITI\%3E2.0.CO\%3B2-J

Intergenerational Transfers and Savings

Laurence J. Kotlikoff

The Journal of Economic Perspectives, Vol. 2, No. 2. (Spring, 1988), pp. 41-58.

Stable URL:

http://links.jstor.org/sici?sici=0895-3309\%28198821\%292\%3A2\%3C41\%3AITAS\%3E2.0.CO\%3B2-0

A Cohort Analysis of Wealth-Age Profiles Generated by a Simulation Model in France (1949-75)

André Masson

The Economic Journal, Vol. 96, No. 381. (Mar., 1986), pp. 173-190.

Stable URL:

http://links.jstor.org/sici?sici=0013-0133\%28198603\%2996\%3A381\%3C173\%3AACAOWP\%3E2.0.CO\%3B2-T

Life Cycle, Individual Thrift, and the Wealth of Nations

Franco Modigliani

The American Economic Review, Vol. 76, No. 3. (Jun., 1986), pp. 297-313.

Stable URL:

http://links.jstor.org/sici?sici=0002-8282\%28198606\%2976\%3A3\%3C297\%3ALCITAT\%3E2.0.CO\%3B2-I

The Role of Intergenerational Transfers and Life Cycle Saving in the Accumulation of Wealth Franco Modigliani

The Journal of Economic Perspectives, Vol. 2, No. 2. (Spring, 1988), pp. 15-40.

Stable URL:

http://links.jstor.org/sici?sici=0895-3309\%28198821\%292\%3A2\%3C15\%3ATROITA\%3E2.0.CO\%3B2-V 